\title{
FILSAFAT PERENIAL DAN DIALOG AGAMA: STUDI PEMIKIRAN SEYYED HOSSEIN NASR
}

\author{
Oleh: \\ Dwi Wahyuni ${ }^{1}$, Syukri Al Fauzi Harlis Yurnalis ${ }^{2}$, Mhd Idris ${ }^{3}$ \\ Universitas Islam Negeri Imam Bonjol Padang123* \\ dwiwahyuni@uinib.ac.id ${ }^{l}$ \\ syukrialfauzi@uinib.ac.id ${ }^{2}$ \\ mhdidris@uinib.ac.id
}

\begin{abstract}
Social conflict as something that no longer only stems from the issue of economic inequality and political interests. However, differences in conceptions between religions and religious prejudice against other religious communities are the causes of social conflicts. The important thing that urgently needs to be done is to create and expand religious dialogue. However, the religious dialogue that has been initiated and practiced over the last few decades still needs to be taken more seriously. This study aims to complete a literature review related to how perennial philosophy can be an alternative approach to a more serious religious dialogue. This study focuses on the thoughts of Seyyed Hossein Nasr several of his works that are relevant to discussions related to perennial philosophy and religious dialogue. The research method was carried out by collecting data using library research techniques. After the data has been collected, then data analysis is carried out using historical descriptive methods. The results of this study indicate that Seyyed Hossein Nasr's perennial philosophy offers an attitude that allows religious dialogue to be more serious and fruitful. With Seyyed Hossein Nasr's perennial philosophy, dialogue is carried out with clear integrity and genuine openness for mutual understanding to take place. Integrity and openness to dialogue with existing differences contribute to understanding differences in conceptions and breaking down prejudices between religious believers.
\end{abstract}

Keywords : Perennial Philosophy, Intellect, Sufism, Dialogue

\section{A. PENDAHULUAN}

Ragam identitas agama dalam kehidupan manusia dapat menjadi faktor integrasi, sekaligus dapat menjadi penyebab disintegrasi. Satu sisi agama menciptakan ikatan bersama. Tetapi di sisi lain, agama sering kali disalahpahami yang menyebabkan agama menjadi faktor perpecahan kehidupan sosial masyarakat. (Dwi Wahyuni, 2017: 83-91) Perasaan seagama saja tidak cukup untuk menciptakan kesatuan 
sosial. Maka harus ada faktor-faktor lain yang lebih memperkuat dan mempertahankan kohesi sosial.

Perbedaan konsepsi antar agama merupakan realitas yang tidak dapat dipungkiri. Perbedaan bahkan benturan konsepsi itu terjadi pada hampir semua aspek agama, baik di bidang konsepsi tentang Tuhan maupun konsepsi pengaturan kehidupan umat beragama. Perbedaan konsepsi cukup sering memicu konflik fisik maupun non-fisik antar umat beragama.

Selain perbedaan konsepsi, prasangka umat beragama terhadap umat beragama lainnya menjadi salah satu penyebab konflik sosial terjadi. Prasangka merupakan salah satu aspek paling destruktif dari perilaku manusia dan sering menimbulkan tindakan mengerikan. (M. Alfandi, 2013: 119) Berbagai kasus konflik sosial antar umat beragama sering diawali dari kesalahpahaman antar umat beragama yang berkonflik.

Cara pandang yang menempatkan agama sebagai sumber konflik, telah menimbulkan berbagai upaya menafsirkan kembali ajaran agama dan kemudian dicarikan titik temu pada level tertentu. Hal penting yang mendesak untuk terus dilakukan ialah menciptakan dan memperluas dialog agama sebagai ruang perjumpaan antar ragam identitas agama. Bila umat beragama telah saling mengenal dan saling memahami satu sama lain, maka umat beragama dapat berkerjasama. Penyelesaian masalah kehidupan sosial yang ideal menuntut partisipasi seluas mungkin dari setiap umat beragama untuk membangun kehidupan harmoni sejati yang kokoh. (Dwi Wahyuni, 2019: 188197)

Dalam dialog, sisi-sisi persamaan antar berbagai agama dimunculkan dan tetap menunjukkan sisi-sisi perbedaannya agar masing-masing umat beragama dapat saling memahami dan menghormati. Dengan terbentuknya kondisi saling memahami dan menghormati, konflik antar umat beragama dapat dihindari. Memang, konflik yang terjadi di banyak tempat sebenarnya tidak ada satu pun yang semata-mata disebabkan oleh faktor tunggal perbedaan agama. Namun tidak dapat dibantah, bahwa pemahaman ajaran agama ikut andil dalam terjadinya konflik sosial.

Dialog bukan sekedar kegemaran intelektual melainkan suatu keharusan. Dialog sejatinya dilakukan dalam kesetaraan, tidak boleh prinsip diabaikan dan tidak boleh sekedar mencari kedamaian palsu. Dialog harus ada kesaksian yang diberi dan diterima guna saling memajukan satu sama lain dalam perjalanan pencarian dan pengalaman keagamaan. Dialog diarahkan untuk menyingkirkan prasangka dan sikap intoleran. Dialog mensyaratkan sikap konsisten, terbuka, kerendahan hati dan keterus-terangan sehingga dialog dapat memperkaya masing-masing pihak. Menurut Olaf Schumann, seorang ahli dialog antar agama di Indonesia: "dialog sama sekali tidak mengurangi kesetiaan yang penuh dan jujur terhadap imannya sendiri, melainkan memperkaya dan 
memperkuatnya. Dialog adalah suatu hal yang asasi dalam menghilangkan salah paham dan prasangka yang pernah timbul di masa silam." (Gerardette P, 2016: Xlv)

Namun demikian, dialog agama tidak lantas selalu dapat menghapuskan kesalahpahaman antar umat beragama. Pendekatanpendekatan dialog agama seperti eksklusivisme, inklusivisme dan pluralisme tidak cukup membantu terwujudnya pelibatan agama-agama dalam dialog yang serius. Meskipun pendekatan pluralisme melampaui pendekatan eksklusivisme dan inklusivisme, namun tetap saja ada bahaya yang timbul, seperti tidak memandang serius ragam identitas yang ada.

Studi pemikiran Seyyed Hossein Nasr sudah banyak dilakukan. Dalam lima tahun terakhir saja ada beberapa akademisi telah menulis pemikiran Seyyed Hossein Nasr, tema artikelartikel yang telah terbit tersebut fokus pada pembahasan hubungan filsafat perenial dengan spiritualitas manusia, sains, nestapa manusia modern, dan ekologi. Studi pemikiran Seyyed Hossein Nasr terkait hubungan filsafat perenial dan spiritual ialah Sayyed Hossein Nasr Tentang Filsafat Perennial dan Human Spiritualitas ditulis oleh Jaipuri Harahap tahun 2017; The EcoPhilosophy Of Seyyed Hossein Nasr: Spiritual Crisis And Environmental Degradation ditulis oleh $\mathrm{Md} \mathrm{Abu}$ Sayem tahun 2019. Studi pemikiran Seyyed Hossein Nasr terkait hubungan filsafat perenial dan sains ialah Traditional Science And Scientia Sacra: Origin And
Dimensions Of Seyyed Hossein Nasr's Concept Of Science ditulis oleh Asfa Widiyanto tahun 2017; Kontribusi Filsafat Perenial Sayyed Hossein Nasr Terhadap Sains Modern ditulis oleh Fitri Siska Supriatna dkk tahun 2020. Studi pemikiran Seyyed Hossein Nasr terkait hubungan filsafat perenial dan nestapa manusia modern ialah Islam Dan Filsafat Perenial: Respon Seyyed Hossein Nasr Terhadap Nestapa Manusia Modern ditulis oleh Fathin Fauhatun tahun 2020. Studi pemikiran Seyyed Hossein Nasr terkait hubungan filsafat perenial dan ekologi ialah Ecological Sufism Concepts In The Thought Of Seyyed Hossein Nasr ditulis oleh Ahmad Sururi dkk tahun 2020.

Studi pustaka terhadap filsafat perenial Seyyed Hossein Nasr dan dialog agama pun sudah ada yang menulis. Tahun 2016 Gerardette Philips menulis buku berjudul Melampaui Pluralisme: Integritas Terbuka sebagai Pendekatan yang Sesuai bagi Dialog Muslim-Kristen, buku ini menjadikan filsafat perenial Seyyed Hossein Nasr sebagai salah satu variabel pemikiran untuk pendekatan integritas terbuka dalam dialog Muslim-Kristen. Tahun 2017 Marz Wera menulis Membingkai Ruang Dialog Beragama: Belajar Dari Hans Küng Dan Seyyed Hossein Nasr. Karena itu, penelitian berbasis studi pemikiran Seyyed Hossein Nasr ini bertujuan untuk melengkapi kajian kepustakaan yang telah dilakukan Gerardette Philips dan Marz Wera terkait bagaimana filsafat perennial dapat menjadi pendekatan alternatif dialog agama yang lebih serius. 


\section{B. METODE PENELITIAN}

Metode studi tokoh mempertimbangkan beberapa aspek penting yang dapat dijadikan sebagai objek kajian, misalnya biografi tokoh tersebut, pemikiran dan karyanya, peranan sosial tokoh tersebut dalam kehidupan masyarakat, dan kontruksi media terhadap tokoh tersebut.

Penelitian ini fokus pada pemikiran Seyyed Hossein Nasr melalui beberapa karyanya yang relevan dengan pembahasan terkait filsafat perenial dan dialog agama. Sumber utama penelitian ini adalah tulisan Seyyed Hossein Nasr yang telah diterbitkan seperti Knowledge and the Sacred (1988), Sufi Essays (1999), The Garden of Truth (2007). Sedangkan sumber sekunder dalam penelitian ini ialah buku Gerardette Philips berjudul Melampaui Pluralisme: Integritas Terbuka sebagai Pendekatan yang Sesuai bagi Dialog Muslim-Kristen (2016) dan beberapa tulisan lain yang relevan dengan pembahasan.

Pengumpulan data dilakukan dengan menggunakan teknik studi pustaka. Setelah data terkumpul selanjutnya dilakukan analisis data dengan metode deskriptif historis. Metode analisis ini digunakan untuk mendeskripsikan konsep-konsep pemikiran Seyyed Hossein Nasr dan pemikiran tokoh lain yang mempengaruhi pemikiran Seyyed Hossein Nasr.

\section{HASIL DAN PEMBAHASAN}

\section{Biografi dan Posisi Filosofis Seyyed Hossein Nasr}

Berasal dari pasangan keluarga ahli bait yang tepelajar di Teheran, Iran pada tanggal 17 April 1933 lahir tokoh bernama Seyyed Hossein Nasr. Dari seorang ibu yang terdidik dalam keluarga ulama dan ayah bernama Sayyed Waliyullah Nasr adalah seorang Dokter, seorang tenaga pendidik di masa dianasti Qajar dan juga seorang Menteri pada masa kekuasaan Reza Pahlevi. (Waryono. AG, 2013: 308)

Kegiatan rutin sejak usia dini yang hampir setiap minggu diterapkan oleh kedua orang tua Seyyed Hossein Nasr untuk mengajarkan ayat-ayat Al-Quran, pengetahuan tentang sejarah-sejarah suci, dan puisi-puisi Persia, menjadikan Seyyed Hossein Nasr memiliki rasa keterbukaan dan rasa ingin tahu akan ilmu pengetahuan. Kata Seyyed Hossein Nasr "yang paling penting adalah berjam-jam diskusi dengan ayah saya, terutama tentang isu-isu filosofis dan teologis, dilengkapi dengan membaca dan reaksi terhadap wancana yang merupakan aspek penting dari pendidikan filsafat saya di usia dini." (Hahn L.E, Rendall E.A \& Stone L.W, 2001: 9)

Selain didikan secara informal yang diberikan oleh kedua orang tuanya, Seyyed Hossein Nasr juga mendapatkan pelajaran dari sejumlah ulama di Qum. Ayah Seyyed Hossein Nasr mengirimnya untuk belajar kepada Muhammad Husin Thabathab'i yang dikenal sebagai seorang penulis tafsir mizan untuk belajar tentang filsafat, ilmu kalam dan tasawuf. Pada usia 13 tahun, Seyyed Hossein Nasr menempuh 
pendidikan formal pada sekolah menengah di Amerika. Namun baru beberapa bulan Seyyed Hossein Nasr tinggal dan belajar di Amerika ayahnya meninggal dunia. (Ali Maksum, 2003: 37)

Selama kurang lebih 20 tahun, Seyyed Hossein Nasr berguru dengan Muhammad Husin Thabathab'i untuk ilmu-ilmu Filsafat, ilmu Kalam dan juga ilmu Tasawuf, serta juga menghafal Al-Quran dan menghafal syair-syair Persia Klasik. Seyyed Hossein Nasr melanjutkan pendidikan formalnya dengan cara mendaftarkan diri ke Universitas termuka yang ada di Amerika untuk mempelajari ilmu Barat modern. Seyyed Hossein Nasr menempuh pendidikan di dua universitas yakni di Massachusetts Institute of Technology (MIT) dan di Harvard University.

Dalam bidang matematika dan fisika, Seyyed Hossein Nasr memperoleh gelar diploma B.S pada tahun 1954 di Universitas Massachusetts of Technology. Lalu di Harvard University, Seyyed Hossein Nasr lulus dengan predikat terbaik dan memperoleh gelar M.A bidang ilmu filsafat dan sejarah. Seyyed Hossein Nasr juga memperoleh gelar Ph.D dalam bidang sejarah, sains dan filsafat Islam pada tahun 1958 dari Universitas yang sama dengan judul disterasi: An Inttronduction to Islamic Cosmological. Setelah selama empat tahun menempuh pendidikan, Seyyed Hossein Nasr langsung membuktikan dirinya sebagai otoritas di bidang Agama Islam, Sains, bidang Filsafat Islam, bidang Sufisme dan dalam bidang Filsafat Perennial. Selama menempuh pendidikan di Amerika, Seyyed Hossein Nasr juga secara otodidak mempelajari ilmu-ilmu Timur seperti ilmu tradisional agama Hindu, Budha dan khususnya tradisi pemikiran Islam,

Dibimbingan George de Santillana, Seyyed Hossein Nasr banyak mendapatkan informasi tentang situasi Barat yang sedang berjuangan untuk menemukan titik temu pandangan antara sains, filsafat dan agama. Seyyed Hossein Nasr juga di mendaptakan informasi tentang pemikiran-pemikiran tradisi Timur melalui tulisan Rene Guenon, F. Schoun serta T. Burckhardt dari tulisan-tulisan merekalah, Seyyed Hossein Nasr dapat berkenalan dengan pemikir metafisika dan juga ajaran-ajaran Timur yang telah banyak mempengaruhi intelektualnya. (Ali Maksum, 2003: 38)

Setelah memperoleh gelar Ph.D, Seyyed Hossein Nasr menyelesaikan perjalanan hidupnya di Amerika untuk menikah dan kembali tinggal di Iran memulai kehidupan barunya di Teheran, Seyyed Hossein Nasr berkerja sebagai tenaga pengajar di Universitas Teheran. Di Teheran, Seyyed Hossein Nasr mengajar di bidang Sejarah Sains dan Mata kuliah Filsafat. Di Universitas Teheran Seyyed Hossein Nasr diangkat sebagai Guru Besar Sains dan Filsafat. Karirnya di dunia intelektual juga mencatatkan dirinya pernah menjadi Dekan Fakultas Sastra Islam (1968-1972) di tahun 1962-1965, menjadi profesor tamu dari Harvard University. Seyyed Hossein Nasr 
pernah menjadi pembantu rektor Univeritas Teheran di tahun 19701971, kemudian Seyyed Hossein Nasr juga menjadi konselor Aryamerh Unversity of Technologi Teheran. Selama kurang lebih 21 tahun Seyyed Hossein Nasr berada di Teheran dan meninggalkan Iran menjelang meletusnya peristiwa bersejarah yakni Revolusi Islam Iran di tahun 1979. (Ali Maksum, 2003: 46)

Setelah memutuskan untuk meninggalkan Iran dan kembali ke Amerika di tahun 1979 ketika menjelang meletusnya Revolusi Iran. Di Amerika Seyyed Hossein Nasr berkerja sebagai tenaga pendidik di Temple University sebagai profesor di bidang Pemikiran Islam. Pada tahun 1985 Seyyed Hossein Nasr mengakhiri tugasnya di Tample Universitas dan pindah berkerja ke George Washington University masih dengan bidang yang sama yakni Pemikiran Islam. Seyyed Hossein Nasr juga sering diundang untuk memberikan ceramah atau menjadi pemateri pada kuliah di berbagai Universitas di banyak Negara seperti Amerika, Eropa, Jepang, India, Australia dan Negara-negara Timur Tengah. Pada tahun 1981 Seyyed Hossein Nasr mendapatkan kesempatan untuk menyampaikan pidato dalam Gifford Lectur yang merupakan forum bergengsi kalangan teolog, filsuf dan Sainstis Amerika dan Eropa, Seyyed Hossein Nasr menjadi muslim dari Timur yang pertama kali mendapatkan kesempatan tersebut. Forum yang berdiri pada tahun 1981 tersebut digunakan untuk menyajikan beberapa aspek kajian tentang kebenaran yang terletak pada pusat jantung tradisi Timur dan hasil dari ceramah pada forum tersebut dipublikasikan dengan judul buku : Knowledge and the Sacred. (Waryono. AG, 2013: 383)

Karya Seyyed Hossein Nasr yang berkenaan dengan Sains dan Filsafat Islam yakni: An Introduction to Islamic Cosmological Doctrines (1964), Science and Civilization in Islam (1968), Islamic Philosophy from its Origin to the Present (2006). Karya Seyyed Hossein Nasr yang berkenaan dengan Islam atau tradisi sufisme yakni: Three Muslim Sages (1964), Idels and Realities of Islam (1966), Islamic Studies (1967), Sufi Essays (1972), Studies in Rumi and Sadr al-Din Shirazi (Mulla Sadra), Islamic Art and Spirituality (1987), Poems of Truth (2007), The Islamic Intellectual Tradition in Persia. Karya Seyyed Hossein Nasr yang berkaitan dengan masalah-masalah modern seperti masalah krisis lingkungan dalam terang metafisika tradisional yakni: The Encounter of Man and Nature (1968), Islam and the Plight of Modern Man (1976), Traditional Islam and the Modern World (1987), A Need for a Sacred Science (1999) Karya Seyyed Hossein Nasr yang berkaitan dengan Dialog Keagamaan yakni: Pada tahun 1994 Nasr di undang untuk memberikan ceramah Cadbury di Universitas Birmgham dengan karya utamanya berjudul: Religion and the Order of Nature (1996). (Gerardette P, 2016: 32)

Warisan spiritual dan intelektual dari filsafat perenial kembali pada tiga tokoh yang sangat penting memberi inspirasi dan penafsir ulang 
pada abad kedua puluh. Mereka ialah Rene Guenon, Ananda K, Coomaraswamy dan Fithojof Schoun. Tiga tokoh ini membedakan diri dari para filsuf lain filsafat perennial dengan berbicara tentang sophia perennis atau religio perennis. Filsafat mereka menjadi filsafat agama yang jelas, mereka juga menyebut diri mereka sebagai kaum tradisionalis. Secara etiomoologis kata tradisi dengan trasmisi dan dalam lingkup artinya mengandung gagasan tentang trasnmisi pengetahuan, praktik, teknik, hukum, bentuk dan banyak elemen lainnya baik yanag bersifat lisan dan tertulis. Tradisi adalah seperti kehadiran yang hidup yang meninggalkan jejaknya, tetapi tidak tereduksi pada jejak itu." (Seyyed Hossein Nasr, 1988: 67)

Sebuah kritik atas dunia modern dari Rene Guenon fokus pada tiga wilayah eksposisi utama: metafisika, inisiasi, dan simbolisme. Masingmasing dari dominan ini memberi para pembaca Rene Guenon apa yang dipahami dengan istilah tradisi. Dalam pemikiran Ananda K. Coomaraswamy pernyataan philoshophia perennis menerima suatu penjelasan baru, kontribusinya terutama ada dalam kemampuannya untuk mengungkapkan hubungan spritual yang menyatukan simbolisme, estetika, kontemplasi dan karya artistik. "Simbolisme dalam tulisan-tulisannya tidak hanya suatu museum referensi dan korespondensi, ia adalah suatu lokakarya hidup dari transformasi spritual." Ananda K. Coomaraswamy mencurahkan banyak perhatian pada Buddhisme, Neo Platonisme dan mistisisme Kristen, termasuk Kristen
Timur. Jika Rene Guenon dan Ananda K. Coomaraswamy dapat dianggap sebagai pelopor sophia perennis dan philosophia perennis pada abad kedua puluh. Berbeda dengan Frithjof Schuon yang cenderung lebih tertarik pada religio perennis ketimbang pada sophia perennis atau philosophia perennis. Dari tiga pelopor filsafat perenial ini, Seyyed Hossein Nasr mengakui 'hutang' intelektual dan spiritual yang lebih langsung kepada Frithjof Schuon daripada kepada Rene Guenon dan Ananda K. Coomaraswamy. Namun, Seyyed Hossein Nasr lebih memilih istilah sophia perennis atau philosphia perennis ketimbang religio perennis. (Gerardette P, 2016: 146-147)

Diantara semua tokoh filsafat perenial, Seyyed Hossein Nasr adalah unik dalam tiga hal; pertama, seorang tokoh publik, pembicara dan juru bicara bagi ide-ide filsafat perenial yang telah diakui di Amerika Serikat dan Eropa. Kontribusi dan partisipasinya dalam event-event lintas agama yang sangat menonjol di PBB dan forum-forum lainnya, membuat Seyyed Hossein Nasr berhubungan dengan orang-orang dari agama-agama yang berbeda. Kedua, Seyyed Hossein Nasr adalah penulis tentang filsafat perenial yang erat diidentifikasikan dengan tradisi keagamaan Islam. Ketiga, Seyyed Hossein Nasr juga merupakan penulis filsafat perenial yang telah menerima pelatihan akademis yang intensif dan maju dalam ilmu-ilmu modern. Seyyed Hossein Nasr mampu menyelidiki secara ilmiah kekeliruan sains yang terputus dari prinsipprinsip metafisik. Semua cara ini 
telah membawa ide-ide perennialis ke dunia kontemporer.

\section{Filsafat Perenial Seyyed Hossein Nasr}

Seyyed Hossein Nasr membedakan pemahaman manusia dalam dua jenis pengetahuan yakni rasional dan intelektif, Pengetahuan sering hanya dianggap sebagai yang rasional, diskursif, dan tidak langsung, namun hal itu tidak demikian halnya dengan pengetahuan intelektif. Menurut Seyyed Hossein Nasr pengetahuan intelektif berasal dari pengetahuan noetik khas yang disebut St. Thomas dan kaum Skolastik sebagai intellectus, bangsa Yunani menyebut nous, kaum Vedantis menyebut buddhi, umat Buddha menyebut prajna dan umat Muslim menyebut 'aql. Bagi Seyyed Hossein Nasr, intelek adalah sumber dari semua pengetahuan yang membuat perbedaan antara akal-budi dan kecerdasan.

Intelek bukan hanya organ untuk mengetahui, tetapi adalah dasar dari keberadaan manusia dan kehadiran Tuhan dalam diri manusia yang memberi manusia akan eksistensi dalam kehidupan. Pertanyaanpertanyaan filosofis yang tidak dapat dihindari tentang siapa manusia? Dari mana manusia berasal? apa yang harus manusia lakukan di dunia ini? Dan kemana manusia akan pergi? Adalah pertanyaan-pertanyaan mendasar yang muncul pada pemikiran manusia. Banyak orang yang menyisikan pertanyaanpertanyaan ini tidak penting, sebagai lain puas dengan jawaban yang diberikan oleh keluarga dan masyarakat atau agama dan sedikit manusia betul-betul berpikir mendalam akan pertanyaan "siapa saya?"

Seyyed Hossein Nasr adalah salah satu dari sedikit manusia yang menggali secara mendalam makna batin kebijaksanaan agama. Seyyed Hossein Nasr berkata: "bagaimana kita memilih untuk hidup di dunia ini, bagaimana kita bertindak dan berpikir dan bagaimana kita mengembangkan berbagai kemungkinan laten dalam diri kita- tergantung sepenuhnya pada jawaban yang kita sediakan bagi diri kita sendiri terhadap pertanyaan mendasar tentang siapa kita, karena manusia hidup dan bertindak untuk sebagian besar sesuai dengan citra yang mereka miliki tentang diri mereka sendiri." (Seyyed Hossein Nasr, 2007: 4).

$\begin{array}{ccc}\text { Seyyed } & \text { Hossein } & \text { Nas } \\ \text { menggunakan } & \text { Sufisme } & \text { untuk }\end{array}$ menjawab pertanyaan "siapa saya?" Dalam tradisi Islam jalan Sufi tersebut menyediakan sarana untuk menentukan jawaban utama bagi pertanyaan dasar ini dan menemukan identitas riil manusia. Jalan tersebut membawa seseorang dari yang eksterior ke interior, dari pelupaan ke mengingat, dari keegoisan ke tidak mementingkan diri sendiri, dan dari kepalsuan ke taman kebenaran, di mana identitas sejati seseorang dapat diwujudkan dan dialami.

Bagi Seyyed Hossein Nasr, identitas manusia yang sebenarnya berada di tingkat yang lebih dalam dari keberadaan manusia itu sendiri “ tingkat yang lebih dalam ini adalah intelek, intelek merupakan pusat 
mikrokosmos manusia dan juga organ pengetahuan unitif yang terkait dengan kecerdasaan. Intelek juga tempat di mana Realitas Ilahiah berada pada pria dan wanita." (Seyyed Hossein Nasr, 2007: 8-9)

Tepat di kedalaman hatinya di mana Realitas Ilahiah berada. Seyyed Hossein Nasr menemukan akar "Aku"-nya, identitasnya dan jawaban bagi pertanyaan "siapa aku?" setelah Sufisme yang membawa seseorang ke jantung di mana seseorang menemukan diri sejati maupun yangTerkasih. Seyyed Hossein Nasr akhirnya bisa menjawab pertanyaan tentang 'siapa aku?' sebagai “ tertanam dalam Realitas Ilahiah, yang merupakan akar utama dari setiap aku" Hal ini tidak berarti bahwa "diri sejati dan sang Tercipta" adalah suatu dualitas karena saat Rumi mengatakan hal itu dalam hati ada ruang hanya bagi satu Aku, yang merupakan akar dari Diri sejati dan Diri itu sendiri. (Seyyed Hossein Nasr, 2007: 11)

Seyyed Hossein Nasr berbicara tentang pertemuan Islam dan agama lain secara jelas dalam bukunya Sufi Essays. Setelah menjelaskan pertemuan antara Islam dan agamaagama lain pada tingkat yang berbeda- historis, legal, teologis, filosofis dan ilmiah, Seyyed Hossein Nasr menulis bahwa pada tingkat esoterisme sufi-lah "Pertemuan yang paling mendalam dengan tradisitradisi lain telah dibuat dan di mana orang dapat menemukan dasar yang sangat diperlukan untuk memahami secara mendalam tentang agamaagama lain. Sufi adalah orang yang berusaha untuk melampaui dunia bentuk, untuk melakukan perjalanan dari keberagaman menuju kesatuan, dari khusus ke Universal. Sufi meninggalkan yang banyak untuk Yang-Satu dan melalui proses ini diberikan visi tentang Yang-Satu dalam yang-banyak. Bagi Sufi, semua dibentuk menjadi transparan, termasuk bentuk-bentuk keagamaan, sehingga mengungkapkan kepadanya asal-usul unik mereka." (Seyyed Hossein Nasr, 1999: 146)

Asal-usul unik tersebut digambarkan sebagai "pusat di mana jari-jari bertemu, puncak yang dicapai semua jalan." Menurut Seyyed Hossein Nasr, hanya visi tentang Pusat tersebut yang dapat memberikan suatu dialog yang bermakna di antara agama-agama, yang menunjukkan baik kesatuan batini dan keanekaragaman formal mereka. (Seyyed Hossein Nasr, 1999: 146).

Penegasan Seyyed Hossein Nasr ini sebagai titik tolak untuk tujuan menunjukkan bagaimana apresiasi spritual dan esensi Islam memperlihatkan betapa Islam bersifat universal dan berkaitan dengan agama-agama lain. Ini juga menunjukkan bagaimana pemahaman Sufi membuka jalan menuju jantung agama itu sendiri, dan bagaimana konsepsi tersebut pada gilirannya membantu untuk menempatkan tradisi-tradisi keagamaan lain dalam sebuah semesta spritual. Dimana Semesta spiritual tersebut akan didefenisikan sebagai 'islam Sejati' yang berarti, Islam sebagaimana di pahami sebagai penyerahan diri universal submissioan kepada God, 
dan bukannya hanya sebagai denominasi keagamaan tertentu.

Berdasarkan kebijaksanaan sufi, dua dimensi penting dari orang-orang dan agama-agama sama-sama dipertimbangkan, yang pertama bersifat jasmani dan yang lainnya rohani. Inilah yang membedakan yang satu dari yang lain. "perbedaan diantara makhluk-makhluk berasal dari bentuk luar (nam); ketika seseorang menembus ke dalam makna batin (ma'na) terdapat perdamaian. Oh hakikat eksitensi! Hal ini karena sudut pandang yang bersangkutan bahwa terdapat berbagai perbedaan antara Muslim, Zoroaster dan Yahudi (Rumi)" (Seyyed Hossein Nasr, 1999: 123)

Dengan menggunakan sufisme, Seyyed Hossein Nasr menawarkan suatu cara untuk belajar agamaagama. Dalam dunia agama-agama, keberagaman adalah bentuk dan persatuan adalah esensi yang merupakan asal-usul segala sesuatu. Agama dapat dipelajari dalam bentuk perlu dijabarkan dan dibandingkan. Sedangkan dalam esensi yang mengarah ke kesatuan batini Tuhan yang satu. Selanjutnya, Seyyed Hossein Nasr menjelaskan bahwa jika esensi muncul sebelum bentuk dan menghubungkannya dengan tatanan ada yang lebih tinggi. Dengan kata lain, "hanya dalam memahami esensi agama maka bentuknya menjadi terpahami sebagai simbol-simbol yang dapat dimengerti dan bukannya fakta buram." (Seyyed Hossein Nasr, 1999: 130).

Dalam doktrin metafisik ini Seyyed Hossein Nasr memandang hubungan Islam dengan agamaagama lain. Dan mendasari seluruh bangunan intelektualnya. Seyyed Hossein Nasr telah mempelajari baik bentuk agama-agama lain dan dalam kasus tertentu, inti mereka dan hari ini dilengkapi dengan sarana intelektual dan spiritual yang diperlukan untuk melaksanakan studi ini dalam keadaan baru yang dihamparkan dunia modern. Seyyed Hossein Nasr menempatkan dengan sifat agama Allah yang diberikan kepada Nabi Muhammad adalah agama yang sama yang diberikan kepada pada pendahulu Nabi Muhammad. Seyyed Hossein Nasr menunjukkan bahwa Islam mengijinkan rahmat para nabi dan orang-orang kudus dari agama-agama sebelumnya (terutama garis Ibrahim) untuk mencapai sang muslim dalam konteks yang disediakan oleh rahmat nabi Islam. Hal ini berarti bahwa seorang Muslim dapat memandang Ibrahim atau Kristus (Nabi isa) bukan sebagai Nabi Yahudi atau Kristen, tetapi sebagai Muslim, dan pada keyantaanya memang demikian. (Seyyed Hossein Nasr, 1999: 130) Karena latar belakang integrasi spritual dalam dunia Islam ini menjelaskan bahwa Islam akan menunjukkan sangat sedikit minat dalam studi sejarah dan doktrin agama-agama lain karena sudut pandangnya sendiri tentang agama adalah yang paling universal.

Islam memiliki dua dimensi, dimensi eksoteris dan esoteris, yakin hukum Ilahiah atau syariah dan cara spritual atau Thariqah. Melalui dimensi esoteris, Islam telah menemui agama-agama lain secara mendalam. (Seyyed Hossein Nasr, 
1999: 133). Historisnya, Islam menemui agama Yahudi dan Kristen dalam masa pertumbuhannya. Selama ekspansi pertamanya ke utara Islam bertemu dengan agama-agama Iran, baik Zoroastianisme dan Manikeisme, di Kekaisaran Sassanid. Seyyed Hossein Nasr menunjukkan pertemuan Islam dengan semua tradisi keagamaan penting di Asia, "dengan menyisikan agama Shinto yang terbatas pada Jepang, tidak ada yang lain yang dengannya umat Muslim tidak memiliki kontak intelektual awal." (Seyyed Hossein Nasr, 1999: 133)

Pertemuan mendalam Islam dengan agama-agama lain adalah 'jalan Sufi'. Doktrin tentang kesatuan ini yang unik pada dirinya sendiri ini (al-Tawhid wahid) disebut kaum Sufi sebagai "agama cinta" dan yang terhadapnya Ibn 'Arabi menunjukkan dalam syair-syairnya yang terkenal dalam Tarjuman al-Ashwaq, "Hati ku telah menjadi mampu menghadapi setiap bentuk: ini adalah padang rumput bagi rusa dan biara bagi orang Kristen yang sebuah kuil utuk berhala dan ka'bah peziarah dan tabel taurad, dan kitab Al-quran saya mengikuti agama cinta: cara apapun yang ditempuh untuk cinta itulah agama saya dan iman saya."

Seyyed Hossein Nasr menegaskan kembali bahwa "Cinta bukan hanya sentimen atau emosi; cinta adalah aspek genosis yang terealisasi. Cinta adalah pengetahuan transenden yang mengungkapakan kesatuan batini agama-agama. “(Seyyed Hossein Nasr, 1999: 147) Pengetahuan transenden ini mengelola perbedaan agama-agama, menemui keunikan masing-masing agama; dan hal ini pada giliranya membawa seseorang dari bentuk ke esensi dimana terdapat kesatuan batini agama-agama. Menurut Seyyed Hossein Nasr, pertemuan dengan agama-agama tetap perlu bagi para Sufi untuk menjelaskan latar belakang metafisik yang dalam terangnya bentuk-bentuk tertentu dapat dipelajari dan dipahami. Sufisme memberikan kunci bagi apresiasi spritual dari esensi Islam dan hubunganya dengan agamaagama lain, bagi umat muslim kontemporerlah kunci itu diperuntukkan. (Seyyed Hossein Nasr, 1999: 150).

Seyyed Hossein Nasr menjelaskan, satu-satunya perjalanan hidup yang bermakna ialah perjalanan seseorang yang telah memperoleh visi tentang puncak gunung. Seyyed Hossein Nasr menulis: "ia yang telah memperoleh visi tentang puncak gunung yang menyentuh ketakterbatasan yakin bahwa para pendaki yang mengikuti jalur lain bagaimana pun juga merupakan kawan-kawannya dalam perjalanan ini, yang merupakan satusatunya perjalanan hidup yang berarti. Kepastiannya datang bukan hanya dari visi tentang puncak itu, tetapi juga dari pengetahuan bahwa jalan yang telah dipilih untuk manusia oleh Tuhan sendiri pada akhirya ke atas, meski ada belokanbelokan dijalan itu." (Seyyed Hossein Nasr, 1999: 150)

\section{Urgensi Filsafat Perenial Seyyed Hossein Nasr Sebagai Upaya Untuk}




\section{Dialog Agama yang Lebih} Serius

\begin{abstract}
Esensi Islam tidak hanya memberikan suatu visi universal tentang agama dan suatu sarana untuk merenungkan semua agama wahyu sebagai tanda-tanda (ayat) Allah, tetapi juga membuka jalan dialog yang kreatif dan konstruktif diantara para pengikut semua komunitas kegamaan yang berbeda. Hal ini memberi dasar untuk dialog dan pengayaan bersama yang melampaui betuk-bentuk eksternal agama ke esensi agama.
\end{abstract}

Dialog agama digambarkan dengan tujuh daratan yang berhubungan satu sama lain. Daratandaratan dialog itu dapat dilihat sebagai langkah-langkah yang fleksibel dan dapat melompat. Dataran-daratan dialog itu juga dapat disebut momen-momen dialog sebab usaha dan tindakan berdialog umumnya tidak berangkat dari titik nol. Dialog juga dapat dilaksanakan pada dataran mana saja yang mungkin pada lingkungan dan waktu tertentu. Dataran-dataran atau momen-momen itu dapat digambarkan sebagai berikut: (1) dialog kehidupan, (2) analisis sosial dan refleksi etis kontekstual, (3) studi tradisi-tradisi agama (saya sendiri dalam komunitas agama saya sendiri), (4) dialog antar umat beragama: berbagai iman dalam level pengalaman, (5) dialog antarumat beragama berteologi lintas agama, (6) dialog aksi (7) dialog intraagama. (J. B. Banawiratma, dkk, 2010: 8)

Memahami dataran-dataran dialog di atas, yang menjadi fokus dalam upaya dialog agama lebih serius ialah dialog antarumat beragama: berteologi lintas agama. Dalam dialog teologis dapat saling berbagi pemahaman agama dalam level ilmiah. Dialog teologis mengkomunikasikan pemahaman yang lebih mendalam mengenai warisan agama masing-masing seraya menghargai dan belajar dari pemahaman tradisi agama lain. Hubungan antaragama yang terbuka dan jujur memerlukan landasan teologis yang terbuka pula. Keterbukaan dalam praktik dan teologi akan menyuburkan satu sama lain. (J. B. Banawiratma, dkk, 2010: 11)

Dialog agama yang telah digagas dan dipraktikkan selama beberapa dekade terakhir masih perlu dilakukan lebih serius. Filsafat perenial Seyyed Hossein Nasr menawarkan sikap yang memungkinkan dialog agama lebih serius dan membuahkan hasil. Dengan Filsafat perenial Seyyed Hossein Nasr, dialog dilakukan dengan berbekal integritas yang jelas dan keterbukaan yang tulus untuk berlangsungnya saling memahami satu sama lain. Integritas dan keterbukaan untuk berdialog dengan perbedaan-perbedaan yang ada memberikan kontribusi pemahaman perbedaan konsepsi dan mengurai prasangka antarumat beragama..

\section{KESIMPULAN}

Penelitian ini menunjukkan bahwa filsafat perenial Seyyed Hossein Nasr tentang esensi Islam akan mampu membuka jalan dialog agama yang lebih serius. Dengan 
intelek yang merupakan dasar dari keberadaan manusia dan kehadiran Tuhan dalam diri manusia, filsafat perenial Seyyed Hossein Nasr menjawab pertanyaan "siapa saya?" Bermodalkan intelek dan jalan para sufi, manusia dapat menjadi diri yang eksterior ke interior, dari bentuk ke esensi yang dimana kesatuan batini agama-agama ditemukan. Dialog agama yang serius harus

\section{Daftar Kepustakaan}

Alfandi, M. (2013). Prasangka: potensi pemicu konflik internal umat Islam. Walisongo: Jurnal Penelitian Sosial Keagamaan, 21(1), 113-140.

Fauhatun, F. (2020). Islam Dan Filsafat Perenial: Respon Seyyed Hossein Nasr Terhadap Nestapa Manusia Modern. Jurnal Fuaduna: Jurnal Kajian Keagamaan dan Kemasyarakatan, 4(1), 54-69.

Hahn, L. E., Umar, M. S., Auxier, R. E., McLean, G. F., Stone Jr, L. W., Khuri, R. K., .. \& Stone Jr, L. W. (2003). The Philosophy of Seyyed Hossein Nasr. Chicago, Open court, The Library of Living Philosophers vol. XXVIII, 2001, 1001 p. Abstracta Iranica. bibliographique pour le domaine irano-aryen, (Volume 24).

Harahap, J. (2017). Sayyed Hossein Nasr Tentang Filsafat Perennial Dan Human Spiritualitas. Aqlania: Jurnal mendialogkan pemahaman yang lebih mendalam mengenai warisan agama masing-masing seraya menghargai dan belajar dari pemahaman tradisi agama lain. Dialog agama yang serius juga dilakukan dengan integritas dan keterbukaan. Integritas dan keterbukaan dapat memberikan kontribusi terhadap kehidupan bersama yang harmoni sejati lagi kokoh.

Filsafat dan Teologi Islam, 8(2), 73-96.

Maksum, A. (2003). Tasawuf sebagai pembebasan manusia modern: telaah signifikansi konsep" tradisionalisme Islam" Sayyed Hossein Nasr. Pustaka Pelajar.

Nasr, S. H. (1988). Knowledge and the Sacred, Lahore: Suhail Academy.

Nasr, S. H. (1999). Sufi Essays. Chicago: ABC International Group.

Nasr, S. H. (2007). The Garden of Truth. San Francisco: Harper Online.

Philips, G. (2016). Melampaui pluralisme: integritas terbuka sebagai pendekatan yang sesuai bagi dialog MuslimKristen. Malang: Madani.

Sayem, M. A. (2019). The EcoPhilosophy of Seyyed Hossein Nasr: Spiritual Crisis and Environmental Degradation. Islamic Studies, 58(2), 271.

Supriatna, F. S., \& Husain, S. (2020). Kontribusi Filsafat Perenial 
Sayyed Hossein Nasr Terhadap Sains Modern. Prosiding Konferensi Integrasi Intserkoneksi Islam dan Sains, 2, 177-183.

Sururi, A., Kuswanjono, A., \& Utomo, A. H. (2020). Ecological sufism concepts in the thought of Seyyed Hossein Nasr. Research, Society and Development, 9 (10), 1-24.

Wahyuni, D. (2017). Agama Sebagai Media dan Media Sebagai Agama. Jurnal Ilmu Agama: Mengkaji Doktrin, Pemikiran, Dan Fenomena Agama, 18(2).

Wahyuni, D. (2019). Gerakan Dialog Keagamaan: Ruang Perjumpaan Antar Umat Beragama Di Kota Bandung. Religious: Jurnal Studi
Agama-Agama Dan Lintas Budaya, 3(2), 188-197.

Waryono A.G, Seyyed Hossein Nasr: Neo Sufisme Sebagai Alternatif Modernisme", dalam Soleh, A. K. (2003). Pemikiran Islam Kontemporer. Yogyakarta: Jendela.

Wera, M. (2017). Membingkai Ruang Dialog Beragama: Belajar dari Hans Kung dan Seyyed Hossein Nasr. Societas Dei: Jurnal Agama dan Masyarakat, 4(2), 165-165.

Widiyanto, A. (2017). Traditional science and scientia sacra: Origin and dimensions of Seyyed Hossein Nasr's concept of science. IntellectualDIscourse, 25(1), 247-272. 